\title{
A polícia corrupta e violenta: os dilemas civilizatórios nas práticas policiais
}

\section{Antonio dos Santos Pinheiro ${ }^{1}$}

Resumo: No Brasil, a transição do estado de exceção para o estado democrático de direito contribuiu para mudanças significativas na concepção de policiamento. Entre outras mudanças, destacam-se: o controle externo da Corregedoria de polícia na investigação e punição aos "maus policiais"; a participação das polícias e da população nos conselhos comunitários, em busca de melhorias para os problemas relacionados à segurança; a preocupação, por parte dos policiais com um tratamento diferenciado aos cidadãos nas abordagens e aos que procuram as delegacias para prestarem queixas; o investimento na formação intelectual nas Academias de Polícias; as exigências para que o governo brasileiro obedeça aos acordos internacionais que estabelecem o fim da tortura como método de investigação. Esse processo encontrou, porém, alguns obstáculos e resistências. Neste artigo, resultado de uma pesquisa realizada entre os anos de 1999 e 2007, na Corregedoria Unificada de Polícias, em Fortaleza/Ceará, apresento algumas denúncias envolvendo policiais militares e civis em atos criminosos tipificados como transgressões disciplinares. Como conclusão da pesquisa, argumento que, por conta da ausência de diálogo e de regras pacíficas entre policiais e civis, a violência policial tem comprometido as expectativas do processo civilizador, que se exerce pelo fortalecimento do monopólio legítimo sobre o uso da força física.

Palavras-chave: Práticas policiais, Controle externo, Monopólio da violência, Violência policial, Polícia Comunitária.

\section{Introdução}

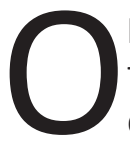

presente artigo, resultado de quatro anos de pesquisa, tomou como ponto de partida uma investigação sobre o papel das polícias em uma sociedade democrática de direito que, no caso específico do Brasil, teve como marco referencial a promulgação da Constituição de 1988. Entre outras questões norteadoras deste trabalho, a violência policial surge como um contraponto às expectativas do processo civilizador, na medida em que compromete a concepção de pacificação social, através da qual as polícias devem ter como missão a preservação da ordem pública e, ao mesmo tempo, o papel de "mediadores de conflito".

Nessa perspectiva, sugiro a partir de Simmel (1983, p. 136) sobre a importância do conflito na construção de redes de sociabilidade. Em casos de violência pela violência, se faz pertinente um questionamento: quando um policial agride civis
Recebido: 10.12 .10 Aprovado: 27.03.13

\footnotetext{
1. Professor Adjunto da Universidade Regional do Cariri, CE

E-mail: antoniopinheiro923@hotmail.com
} 
2. Michel Misse (1997), em uma discussão sobre o mercado ilegal no Rio de Janeiro (1997), fez uma discussão interessante sobre o conflito como competição e a corrupção policial como mercadoria política. 0 autor sustenta que certos tipos de criminalização contribuíram para banalização de ligações perigosas entre práticas ilícitas da polícia e estes vários mercados. deliberadamente não estaria pondo em prática um tipo de vingança pessoal? Em resposta a essa questão, Simmel sugeriria que existe diferença entre o conflito como competição e vingança ${ }^{2}$. Para o primeiro, implica dizer, que o resultado de uma ação conflituosa não constitui propriamente a finalidade ou meta desejada. No segundo, ao contrário, "a cólera, o castigo ou o valor ideal da vitória" impulsionam e motivam deliberadamente as ações dos indivíduos.

Na sociedade brasileira, compreender o papel delegado aos policiais como "mediadores de conflito" pressupõe duas dificuldades: a primeira, diz respeito à possibilidade de superar o legado de violência ditatorial, incorporado na formação policial; a segunda, diretamente relacionada à primeira, é que as práticas sociais, como uma construção coletiva, estão relacionadas aos valores culturais e sentimentos cognitivos compartilhados no interior dos grupos sociais que, como nos lembra Bourdieu (2002), há algo de arbitrário no cultural que, ao ser simbolicamente construído nas relações de dominação, transforma-se em dado naturalizado.

Problematizo que os dilemas entre "velhas práticas" e "novas práticas" policiais permitem questionar a constituição de uma "nova polícia" que, no plano da apresentação, pretende cumprir com as determinações do direito facultado aos cidadãos, mas, na prática pode recorrer à violência física ou simbólica na solução dos conflitos sociais. Ao invés dos acordos formais, observamos que, geralmente, em casos de abordagens a grupos ou indivíduos a violência não comedida torna-se, na maioria das vezes, a máxima de um poder, onde os métodos não convencionais são regra e não exceção. Essa lógica tem comprometido as expectativas do processo civilizador que pressupõe o respeito e a obediência aos códigos formais dos princípios estabelecidos pelo estado democrático de direito.

A não obediência às regras formais do direito, que Zaluar (1998) definiu como "dilema civilizatório", manifesta-se por práticas sociais afastadas das instituições sociais e do respeito à justiça, mas próximas das pessoas que se apropriam do poder sobre o exercício da violência para benefício próprio. Em um dos sambas enredos cariocas, Zaluar descreve que os dilemas e paradoxos de uma vida regulada nos enredos são resultantes de relações pessoais do malandro com o chefe de polícia local. Intitulado "Bloco das Sete", título inspirado em uma portaria policial que proibia o consumo de bebida após as sete horas, o autor do enredo faz a alegoria de um boneco sambando em cima de um barril de aguardente. Estes e outros sambas, escritos por compositores, revelavam os enigmas da violência e do respeito às ordens na sociedade brasileira.

No problema em se estabelecer parâmetros formais na solução dos conflitos, 
não são poucas as dificuldades, como ressalta Habermas (1997), na construção do consenso entre grupos diferenciados que compartilham projetos para o bem comum. Em casos, no entanto, onde a comunicação entre pares não é possível de se estabelecer, o rigor no uso da força física pode se tornar mais eficiente do que a capacidade de uma solução dos conflitos sociais, com base nos acordos dialógicos. Na ausência de um entendimento dialógico, seria possível fortalecer o controle democrático sobre as práticas policiais? O perigo disso, como nos lembra Arendt (1994), é que, na dificuldade de entendimento acerca dos direitos em fazer parte de uma comunidade cidadã e democrática, o exercício do poder na vida pública acabe se tornando uma prática obsoleta e vazia.

Discuto a importância do controle externo praticado pela Corregedoria integrada de polícias como um possível canal de acesso à justiça e a uma polícia comunitária e cidadã, através da conscientização da população, sobre a importância em denunciar os policiais infratores. Como fóruns participativos, estes órgãos se notabilizam pela capacidade em aplicar regras, de acordo com o direito facultado à resistência das vítimas aos agressores "representantes da lei". A Corregedoria se configura como um espaço de vigilância externa sobre os considerados "vigias" do poder - atores legitimados pelo Estado para o exercício da violência (LEMGRUBRER, 2003).

Em uma sociedade da violência, a reconstrução do espaço público pelo diálogo não é uma tarefa fácil. A formalização das denúncias apresenta-se, assim, como um dado importante na construção de canais participativos entre estado e sociedade civil, na configuração de um espaço público, onde o respeito aos direitos humanos se constitua como direito facultado às organizações policiais em garantirem a proteção física e moral dos indivíduos. Nesses casos, problematizo que as práticas criminosas de policiais, em abordagens ao cidadão e na investigação de crimes, configuram a falta de entendimento em cumprir a missão de zelar pelo respeito ao cidadão. Apontamos que casos dessa natureza apresentam-se como pontos de inflexão para o fortalecimento do monopólio da violência.

Os dados apresentados neste artigo resultaram da leitura e da análise de 68 processos denúncias encaminhados à Corregedoria das Polícias, envolvendo policiais militares e civis em atos criminosos tipificados como transgressões disciplinares, entre os anos de 2001 a 2007, na cidade de Fortaleza/Ceará. Com o objetivo de uma melhor compreensão dos casos de violência policial, apresento algumas denúncias envolvendo policiais militares e civis em atos criminosos tipificados como transgressões disciplinares. Como conclusão da pesquisa, argumento que, por conta da ausência de diálogo e regras pacíficas entre policiais e civis, a violência policial tem comprometido as expectativas do processo civilizador, que se exerce pelo fortalecimento do monopólio legítimo sobre o uso da força física. 


\section{Os direitos humanos como "coisa de polícia"}

As discussões em torno da necessidade do reconhecimento dos aparelhos policiais como "promotores dos direitos humanos" apontam que quaisquer mudanças na concepção de poder implicam, primeiramente, o questionamento acerca do uso da violência nas sociedades democráticas e contemporâneas. Nessas sociedades, cabe, portanto, à polícia administrar os conflitos de acordo com as direções adotadas pelos princípios democráticos, onde a participação da sociedade civil torna-se imprescindível para o controle sobre o uso da violência e as cobranças pela legitimidade nas práticas policiais.

Tavares dos Santos (1989), ao discutir a questão da governabilidade em Foucault, argumenta sobre a razão de Estado e a racionalização do aparelho policial nas ações dos governos. Em um contexto democrático de direito, a polícia é o agente que detém o monopólio sobre o uso da violência legítima e seu poder torna-se reconhecido pela capacidade de produzir consenso. Ao longo desse processo, a monopolização da força física, como ressalta Weber (1999), permite aos grupos especializados do Estado assegurarem que a violência seja uma força disciplinada, cuja finalidade é a crença na legitimidade.

O exercício legítimo da violência permite, dessa forma, que as penalidades se exerçam menos no suplício do corpo que na razão da justiça em aplicar a sanção, de acordo com os princípios de universalidade do direito (FOUCAULT, 1987). A positividade do poder na constituição das práticas policiais é, portanto, menos o uso da violência que a arte de governar os corpos e as mentes dos homens. $\mathrm{Na}$ análise sobre a eficiência da violência nas instituições sociais, Foucault argumenta, a partir de Weber (1991), que, na conduta das ações que advém da razão estatal, existe uma racionalidade que lhe é peculiar. O que está em jogo nessa mecânica de poder é a economia dos gestos, o que faz com que cresçam as forças de resistências e a eficácia daquilo que as sujeita. O problema, como ressalta Foucault, é quando essa racionalidade se exerce como força violenta no exercício sobre o controle e autocontrole sobre o "poder de polícia".

Tomando como referência o "exigir e dar satisfação" nas sociedades duelistas do século XIX e XX, na Alemanha, Elias (1997) aponta pistas para compreender a importância do controle e autocontrole das pulsões agressivas nas relações sociais. Ressalta que, entre os "iniciados" nos grupos duelistas, a resolução dos desafetos com os inimigos obedecia a códigos "pacíficos" de conduta, onde, por exemplo, não era permitido às partes desferirem golpes em partes vitais do corpo. Os duelos, ao contrário das brigas comuns, exigiam dos opositores a observância às regras pré-estabelecidas no exercício da violência. Em situações onde os códigos formais não eram obedecidos, os alemães costumavam se sentir fragilizados diante de um Estado "ineficiente" em estabelecer o controle 
sobre as ações individuais.

O entendimento de que uma ação legítima deva primar pelo respeito aos direitos humanos permite, por outro lado, questionar o compromisso da polícia com as mudanças na aplicação da lei e da ordem. Na prática, as ações policiais violentas sugerem controvérsias e paradoxos sobre a legitimidade do uso da violência. Com o objetivo de reverter esse quadro, alguns civis que se sentiram lesados pelos representantes do Estado têm recorrido à Corregedoria mostrando a sua insatisfação e indignação quanto ao indevido cumprimento das regras legais pertinentes ao uso controlado da força física.

\section{O descontrole nas práticas policiais}

Nas denúncias apresentadas à Corregedoria, os conflitos entre policiais e moradores dos bairros, em Fortaleza, sugerem a este estudo que o uso da violência, longe de seguir os parâmetros estabelecidos pelos códigos formalizados de conduta policial, orienta-se por códigos de comportamento que não são, propriamente, os que garantem o devido controle e autocontrole no uso da violência. Kant de Lima (2012) e Paixão e outros (1992), ao discutirem sobre o poder de polícia, argumentam que, na sociedade brasileira, o formalismo jurídico nem sempre se faz presente no controle sobre as práticas policiais permitindo, assim, que os policiais orientem suas ações de acordo com códigos morais de ordem prática.

A participação da população, ao cobrar por parte dos policiais um tratamento justo e respeitoso, permite, ao mesmo tempo, acionar um controle sobre o uso de práticas agressivas no exercício de policiamento. Nos casos denunciados, é possível levar em conta que a sociedade civil tem demonstrado insatisfação, repugnância e vergonha contra policiais que não têm cumprido seu papel como "agentes pacificadores".

As acusações aos policiais civis e militares diferem. Nos processos denúncias envolvendo policiais civis, os mais comuns são relativos a práticas envolvendo crimes de extorsão. Além disso, eles são acusados de facilitarem a fuga de presos, de não comparecerem aos julgamentos, na condição de testemunha, e no que toca o tratamento dispensado às comunidades. No caso dos policiais militares, pelo fato de serem em maior contingente, se comparados aos policiais civis, e estarem em maior contato com a população, são, geralmente, acusados de práticas de agressão física e moral e abuso de autoridade.

A importância atribuída ao papel das polícias como aplicadoras da lei e da ordem contra aqueles que cometem crimes sugere, por outro lado, que o uso 
não comedido da força física, por parte de policiais militares e civis, em algumas operações de policiamento ostensivo e investigativo, pode resultar em casos onde estes, ao invés de serem vistos como forças que defendem o cidadão, são, ao contrário, percebidos como uma arma adicional na proliferação da violência. Em um dos casos denunciados, a sindicada conta que seu filho foi espancado por policiais militares, sendo, posteriormente, perseguido, alvejado e morto a tiros:

Aos 06 do mês de Novembro de 2001, uma senhora compareceu à Corregedoria para denunciar agressão física seguida de morte contra seu filho, causado por um polícia militar, no bairro Vila Velha. Conta que estava em sua residência, quando seu filho chegou carregando dois capacetes e, em seguida, um moto taxista, juntamente com dois PMs, se aproximaram e perguntaram pelos capacetes. No momento, o rapaz devolveu os capacetes e os policiais deram voz de prisão e fizeram uma busca de arma. A partir de então, começou a ser agredido com murros, chutes e golpes de cassetetes e pediu para ser preso e algemado, mas não foi atendido. Em decorrência da agressão, ficou desacordado por alguns minutos e, ao recuperar os sentidos, tentou entrar em sua residência, mas foi perseguido e alvejado com três tiros, vindo a falecer no local. (PROCESSO EM SINDICÂNCIA, denúncia apresentada por um civil, em novembro de 2001)

Em situações onde o cumprimento à lei baseia-se no princípio da garantia do direito à contestação, o mandato judicial é representado, como nos lembra Foucault (1987), como um instrumento jurídico legítimo e legal que autoriza aos representantes da lei agirem de acordo com as prerrogativas do direito de punir os corpos "sem no entanto ser violenta; pode ser calculada, organizada, tecnicamente pensada, pode ser sutil, não fazer uso de armas nem do terror e, contudo, continuar a ser de ordem física".

A produção dos corpos pelas técnicas disciplinares do poder-saber pressupõe que determinadas práticas policiais obedeçam ao princípio da autorização que possibilita e reforça os efeitos do poder legítimo. No caso relatado pela denúncia descrita abaixo, conta o sindicado que os policiais invadiram sua residência e, ao serem questionados sobre seu poder de agirem como tal, foram enfáticos na resposta "você vai comigo seu cachorro, não quero saber de ordem judicial":

Aos 12 de Dezembro de 2004, um senhor comparece para denunciar a agressão física sofrida por parte de policiais civis no bairro do Parque Novo Mondubim. Conta que se 
encontrava em sua residência, quando recebeu a visita de dois homens, que se identificaram como policiais civis e entraram em sua casa, sem autorização judicial para levá-lo à força, sendo que um deles, disse "você vai comigo, seu cachorro, não quero saber de ordem judicial". No trajeto até a delegacia conta que o mesmo policial havia ofendido sua esposa, ao dizer "uma cachorra negra daquela comigo é do jeito que eu quero" e acrescentou que, quando chegasse à delegacia, ele levaria uma surra e que, dali em diante, haveria policiamento para uma determinada família que só vivia brigando. Afirma que logo que chegou à delegacia, o referido policial Ihe deu uns socos e, em seguida, foi colocado na cela, juntamente com outros presos. No momento em que prestava depoimento ao escrivão, afirmou que havia discutido com um vizinho, bem como seus filhos. Ao final do depoimento, o escrivão disse que assinasse, mas, por desconhecer o conteúdo do documento recusou-se a assinar. Neste momento, passou a ser agredido pelo escrivão que disse "eu vou pegar um pedaço de pau", e, enquanto isto acontecia, o policial que havia espancado havia dito: "É melhor você assinar, esse homem é doido. É acostumado a bater em preso, eu acho melhor você assinar". O escrivão pegou um pau e começou a ameaçá-lo. Este policial o jogou contra a parede causando arranhões no cotovelo, nos braços e nas unhas. Antes mesmo de ser convocado a assinar o documento, o polícia havia dito, no xadrez: "Olha, cachorro, eu vou dar dez reais para cada preso dar uma surra em você a noite todinha, caso você não assine a folha lá em cima". (PROCESSO EM SINDICÂNCIA, denúncia apresentada por um civil, em dezembro de 2004)

No caso acima descrito, o policial além de descumprir a ordem de mandato judicial que garante a inviolabilidade de domicílio, não tinha provas suficientes que pudessem incriminar os acusados. O sindicado conta que, após as agressões, um policial civil chegou a pegar um pau com o objetivo de intimidá-lo e acrescentou a denúncia de que este, não satisfeito com as sessões de espancamentos, disse que iria pagar uma quantia em dinheiro aos presos caso ele se recusasse a assinar a folha em que constavam os autos da ocorrência. Nos autos do processo, o sindicado questiona mesmo a possibilidade de não haver provas suficientes que o incriminassem, não escapou do abuso de autoridade praticado por policiais civis.

Como consta nos autos dos processos, não são poucas as situações em que 
os policiais, ao invés de reforçarem a autoridade que lhes é conferida como representantes da ordem pública, buscam beneficiar-se do cargo que lhes é outorgado em benefício próprio, principalmente, quando são ameaçados pelos sindicados:

\begin{abstract}
A 01 de dezembro de 2006, uma senhora compareceu à sede da Corregedoria para denunciar agressão física praticada por um policial militar, no bairro Damas. Conta que se encontrava em sua casa, ouvindo música e que havia recebido uma comunicação do porteiro de seu prédio, informando que a moradora do apartamento debaixo do seu havia se queixado do som alto, e que, mesmo tendo atendido à solicitação para diminuir o volume, teve a porta arrombada e que foi destratada por um policial, identificado como esposo da moradora que havia feito a reclamação. O policial chutou o aparelho de som e, quando uma amiga disse que iria chamar a polícia, foi agredida fisicamente pelo militar que disse "vagabunda, a polícia sou eu". Disse que ela poderia até chamar a polícia, mas que não iria dar em nada, porque quem mandava ali era ele. (PROCESSO EM SINDICÂNCIA, denúncia apresentada por um civil, em dezembro de 2006)
\end{abstract}

Casos como esses apontam para a circunstância de que os policiais agressores, quando se sentem tolhidos de expressarem sua "autoridade", costumam perseguir as vítimas, na intenção de inibi-las pela "ousadia" de denunciá-los. Para isso, contam ainda com os favores do espírito corporativista da profissão, com o objetivo de saírem ilesos da punição. Em casos dessa natureza, existe a possibilidade de que a ameaça ocasione na não formalização da denúncia, em decorrência da possibilidade do infrator ser beneficiado pela justiça.

\title{
O corporativismo profissional como obstáculo
}

A concepção de que existe, no serviço público, uma dominação pessoal contrapõe-se à dominação racional em Weber (1999), em que a legitimidade da função é racionalmente justificada pela finalidade que objetiva o mérito profissional atribuído ao indivíduo e não pelos sentimentos pessoais relacionados à pessoa que exerce o cargo. Em uma ordem legal e racional, na qual a profissão policial é justificada pela noção de dever, a instituição policial é representada como um protetor do cidadão e não como uma pessoa que pretende preservar os interesses privados de classe. Ao contrário dos interesses pessoais típicos de uma comunidade tradicionalmente sob a égide do mando, em sociedade de 
interesses racionais, a regra é que o princípio individualista da profissão seja mais importante que a figura da pessoa ofendida.

Em seu estudo sobre os processos e os autos de querelas, no século XIX, Velasco (2004) sugere que casos, como abuso de autoridade, contribuem para o questionamento sobre o monopólio legítimo da violência. Com base no argumento de que, na formação do campo da justiça no Brasil, a disputa pelo monopólio da violência legítima oscilou entre os poderes públicos e privados, questionou os interesses corporativistas da justiça nos julgamentos e na aplicação da lei. Os próprios órgãos responsáveis pelo controle externo do exercício policial não escapam, da mesma forma, do corporativismo, que, em determinadas situações e, dependendo do grau de interesse do policial corregedor, os desfechos do processo podem resultar em ganhos ou perdas para o sindicado.

No acompanhamento dos processos em julgamento na Corregedoria, os interesses corporativistas não estão, assim, complemente ausentes. Por essa razão, alguns corregedores, que se consideram "imparciais", preferem não acompanhar sindicância, envolvendo colegas de profissão. Com o intento de evitar interferências valorativas e preconceitos de classe, é aconselhável, geralmente, que os corregedores policiais civis acompanhem casos envolvendo policiais militares e vice-versa. Entre os motivos dessa orientação, está a necessidade de uma análise imparcial, no sentido de que a decisão tomada não cause constrangimentos pessoais e profissionais nas relações entre o policial infrator e o policial corregedor.

Na opinião de uma delegada corregedora, "não é fácil lidar com questões que dizem respeito aos seus colegas de profissão". O motivo que pode impossibilitar uma análise imparcial está relacionado à existência de corporativismo profissional, ao passo que qualquer decisão que venha causar prejuízos a um colega de profissão pode gerar uma situação constrangedora. A delegada considerou que o comum é associar o papel dos corregedores a "carrascos da polícia" e policiais que podem causar incômodo aos interesses profissionais e pessoais. Para ela, por outro lado, é preciso deixar claro que "não é que a gente queira punir os colegas, o que a gente quer é corrigir os maus policiais".

Como descrito na denúncia abaixo, o sindicado relata que não foi prontamente atendido em suas reivindicações, ao fazer a denúncia contra um policial militar, pois, ao chegar ao quartel em que o mesmo se encontrava, havia sido informado de que o caso não seria resolvido. Com a deliberação de não ser lesionado, procurou o programa Barra Pesada ${ }^{3}$ (programa policial) e procedeu a denúncia em público:
3. O programa Barra Pesada, apresentado pela TV Jangadeiro do Ceará (filiada à Bandeirantes), é exibido diariamente pelo apresentador Nonato Albuquerque. A pauta do programa é a mais variada possível, tais como: casos de violência doméstica, acidentes, casos de furtos e roubos, violência policial, etc. No programa, os repórteres dão a oportunidade para que os entrevistados possam fazer reclamações relacionadas a casos de violência, inclusive os praticados pela polícia. 
4. A maioria dos policiais com quem conversei, ao longo da pesquisa, afirmaram que preferem trabalhar em outros bairros que não sejam o seu local de residência e de seus familiares. A justificativa, segundo eles, é que, além de evitarem contatos com os civis da área, não correriam, por outro lado, o risco de terem que intervir em casos que envolvam amigos ou familiares. No primeiro caso, o enfrentamento direto poderia gerar um "conflito de autoridade" e, no segundo, um maior comprometimento como defensor exclusivo de pessoas mais próximas, o que poderia ocasionar uma rixa pessoal, pelo fato de a intervenção feita fugir à regra da impessoalidade da lei.
Aos 06 do mês de setembro de 2001, um senhor compareceu à Ouvidoria da Polícia Militar para denunciar o espancamento sofrido por parte de policiais militares, que veio à tona pelo programa policial de televisão Barra Pesada, no bairro Jardim das Oliveiras. Contou que, ao chegar à rua do bairro, encontrou algumas pessoas bebendo e, em seguida foi chamado em advertência por dois desconhecidos, que o acusaram de estar olhando uma residência para assaltar. Os dois o agarraram, e seu amigo, e chamaram a viatura para averiguar seus antecedentes criminais, afirma que respondeu que era um cidadão. Quando a viatura chegou ao local, os mesmos foram algemados sem que fosse dada voz de prisão e qual seria o motivo da prisão. Após a viatura parar, os policiais ordenaram que descessem já com cassetetes nas mãos e pediu para que não Ihe batessem, pois, eram cidadãos e pais de família, no entanto, os policiais disseram que ficassem de costas e, neste momento, passaram a agredi-los com pancadas de cassetetes. Ao comparecer ao quartel da polícia para prestar a denúncia, não havia sido atendido, porque o agressor se encontrava no local e disse que o tenente que havia tomado conta do caso não resolveria, então procurou o programa Barra Pesada para fazer a denúncia. Após a denúncia se tornar pública, o Comando da Polícia designou um oficial para ouvi-lo, mas, quando chegou em sua residência, percebeu que policiais em uma viatura passaram e permaneceram por alguns minutos próximos à sua residência. Por medo, saiu de casa e foi para a residência de seu pai. (PROCESSO EM SINDICÂNCIA, denúncia apresentada por um civil em Setembro de 2001)

Os casos de agressão policial, na maioria das vezes, não chegam ao conhecimento da Corregedoria de polícia, devido ao medo de retaliações. As vítimas nem sempre têm coragem de entrar em conflito com os policiais, principalmente se vítima e agressor residirem em um mesmo bairro ${ }^{4}$. Em alguns processos, por exemplo, os polícias alegam plena confiança de que a denúncia não irá dar em nada pelo fato de não acreditarem na punição:

Aos 07 de outubro de 2005, compareceu um senhor para prestar queixa de agressão física praticada por policiais militares no bairro do Conjunto Ceará. Segundo o declarante, trafegava em sua moto por uma rua do bairro, quando foi abordado pelos policiais, que estavam 
em uma viatura e ouviu o disparo de uma arma de fogo. No momento, desceram da viatura e disseram "bota a mão na cabeça, seu vagabundo", que respondeu que não era vagabundo, quando ouviu "cale a boca, vagabundo, você é um merda". Conta que um deles aplicou um soco quando ainda estava de capacete quebrando a viseira, o outro retirou a sua carteira e the deu um soco na região do fígado, quando caiu ao chão levou um chute. Quando lhe perguntaram sua profissão disse que era autônomo, o que foi contestado pelos policiais como mentira, e se repetiram as agressões verbais. Afirma que, ao saírem do local, disseram ao declarante que ficasse à vontade para anotar a placa da viatura. (PROCESSO EM SINDICÂNCIA, denúncia apresentada por um civil em outubro de 2005)

Em alguns casos como esse, não é incomum, por medo de represálias, os denunciantes desistirem do processo, alegando, como motivos principais, que foram precitados na denúncia ou que o processo está demorando. Quando isso ocorre, a vítima costuma dirigir-se aos órgãos competentes para solicitar o arquivamento do caso, mas os corregedores são instruídos a não encerrarem a sindicância, pois, do contrário, entendem que estariam contribuindo para a impunidade.

A perspectiva de que a impunidade possa gerar um desgaste nos laços de dependência entre Estado e Sociedade, como assinala Dahrendorf (1997), encontra respaldo no argumento de que o aparelho estatal não estaria protegendo os cidadãos ao simplesmente justificar a necessidade de aumento na força policial. Aponta ele como principal causa desse processo, que definiu como erosão na lei e na ordem, uma situação de incerteza na aplicação dos dispositivos de segurança em decorrência de casos em que as violações resultam no "amolecimento das punições" e na quebra de expectativas que ligam os cidadãos entre si e ao Estado.

A incidência de crimes de abuso de autoridade, extorsão e agressão cometidas por policiais nas sindicâncias, sugerem, portanto, quebra de expectativas no processo civilizador. As reivindicações por justiça social, quando postas em xeque, comprometem o respeito às regras formais de convivência social no que diz respeito à integridade física e moral dos cidadãos. Soares (2006) destacou, em seus relatos, os efeitos brutais da violência policial na cidade do Rio de Janeiro que, em decorrência do desrespeito aos direitos civis, a população chegou a generalizar a ideia de que "polícia é pior que bandido". Conclui que, se as polícias respeitassem as leis e as fizessem respeitar, viveríamos uma verdadeira revolução democratizante e civilizatória.

Nos conflitos entre policiais e civis, a possibilidade de que as expectativas civilizatórias sejam desgastadas, aponta que as violações ao direito, ao se tornarem comuns, têm contribuído para a desconfiança na aplicação da lei e da ordem. 
No caso abaixo, por exemplo, a sindicada denuncia que sofreu agressões e queixa-se que desconhece as razões pelas quais seu marido sofre perseguição policial. Reclama que o policial agressor é temido e evitado no bairro e que o mesmo costuma zombar das pessoas, desafiando-as a denunciá-lo com o argumento de que "a denúncia não vai dar em nada":

Aos 03 do mês de fevereiro de 2004, compareceu uma senhora para prestar denúncia na Corregedoria de agressão física, praticada por um policial militar, no bairro Álvaro Weyne. Conta que estava em sua residência, quando a vizinha veio avisar que seu marido tinha sido algemado por um policial e, quando chegou ao local, para ver o que estava acontecendo, os policiais perguntaram o que seu marido fazia, no momento, e ofenderam-na chamando-a vagabunda. O policial queria que o marido da declarante o levasse até sua casa e, como negou, foi agredido com uma tapa na cara e um chute nas pernas, e, em seguida, colocaram-no na viatura que iria leválo para delegacia. Depois, recebeu uma ligação que ele havia sido liberado. Ao chegar em casa, viu que ele estava lesionado, sem poder andar direito, em consequência das agressões sofridas e que não é a primeira vez que isto ocorre, envolvendo o referido policial. Disse que todos o temem no bairro, não sabe por qual razão o militar persegue seu marido, pois o mesmo não tem problema com a justiça. Este policial costuma zombar das pessoas, dizendo que as mesmas podem denunciá-lo à Corregedoria, pois a denúncia não vai dar em nada. (PROCESSO EM SINDICÂNCIA, denúncia apresentada por um civil, em fevereiro de 2004)

A possibilidade que as agressões policiais resultem de uma "cultura autoritária" está, sobretudo, presente no conservadorismo de alguns polícias, ou seja, encontra adeptos entre aqueles que consideram que as polícias não se desvincularam de uma "herança maldita" presente na concepção de que "eu sou polícia e o outro é o bandido". Essa "herança maldita" surge relacionada, em algumas denúncias, por conta da certeza da impunidade e, por essa razão, os policiais costumam manipular provas com intenção de incriminar o denunciante.

Em muitos casos, o medo dos denunciantes em se tornarem vítimas de uma situação forjada de flagrante, gera uma situação constrangedora, pelo fato de saberem que poderão ser "culpabilizados" pelos policiais, por um crime que não cometeram e temem, dessa forma, em responder pela existência de provas forjadas, que escapam aos procedimentos formais, com base na justiça e na transparência: 
Em 29 de abril de 2002, em um processo encaminhado à Corregedoria, a denunciante afirma que teve sua casa invadida por dois policiais, um civil e um militar. O motivo da invasão decorreu devido a uma denúncia feita por moradores de seu bairro de que a mesma teria escondido maconha em sua residência. A declarante contestou a denúncia, alegando que, juntamente com seu marido, são trabalhadores. Acrescentou que o policial civil antes já havia Ihe procurado para solicitar uma quantia em dinheiro, como não pôde ceder o dinheiro solicitado, uma quantia de duzentos reais, o policial disse que iria lhe "dar um bote" de madrugada em sua residência. A declarante confessa que se sentiu temerosa com a ameaça, pelo fato de se tornar vítima de um flagrante forjado, para incriminá-la. (PROCESSO EM SINDICÂNCIA, denúncia apresentada por um civil, em janeiro de 1999)

A invasão de domicílio é apontada como comum na maioria dos casos denunciados à Corregedoria. Em relação a essa sindicância, o Corregedor Auxiliar concedeu parecer favorável à denunciante, alegando que o policial civil infringiu as disposições do artigo 103, letra " $b$ ", inciso I - em não ser leal às instituições que representa - e no inciso II, pelo fato de não proceder na vida pública de modo a dignificar a função policial e, também, no inciso XLVI, ao praticar ato definido em lei, como "abuso de poder" (artigo 2, b, Lei n. 4.898/65).

Na denúncia relatada abaixo, o sindicado denunciou que os policiais além de invadirem sua residência sem mandato judicial, ainda cometeram crime de extorsão ao exigirem a quantia de $\mathrm{R} \$ \mathbf{6} 600$ (seis mil) reais, para relaxar a prisão do sindicado:

Aos 29 do mês de novembro de 2004, compareceu à sede da Corregedoria uma senhora para denunciar invasão de domicílio, praticada por policiais civis, no bairro do Vicente Pinzón. Disse que se encontrava em sua residência, almoçando, quando um dos policiais entrou e fez uma busca e encontraram 2,5 de cocaína, pertencentes a seu companheiro, que é viciado em drogas. Os policiais revistaram sua casa, mas não apresentaram mandato judicial e, após isso, algemaram e prenderam seu companheiro, colocando-o dentro da viatura e que, decorrido algum tempo, seu companheiro retornou, dizendo que os policiais haviam exigido a quantia de $\mathrm{R} \$ 6.000,00$ (seis mil reais) para não levá-lo para a delegacia, preso em flagrante delito. Pelo fato de não dispor da quantia solicitada, disse que entregaria sua moto e, ao entregar a moto, um 
dos policiais exigiu que ele assinasse o documento de transferência. Declarou que não é a primeira vez que o citado policial pratica extorsão. Há quatro anos, a denunciante disse que foi obrigada a vender um imóvel e passar a quantia de $\mathrm{R} \$$ 16.000,00 (dezesseis mil reais) ao comissário de polícia para que não levasse seu companheiro para a delegacia. A declarante, apesar de ter se comprometido a apresentar testemunhas, teme ser vítima de represálias pela denúncia efetuada. (PROCESSO EM SINDICÂNCIA, denúncia apresentada por um civil, em novembro de 2004)

No caso abaixo descrito, conta a denunciante que sofreu agressões praticadas por policiais militares quando estes invadiram sua casa, sem mandato judicial e, além disso, espancaram seus filhos, com chutes e cassetetes. Ao ver a situação de desrespeito à inviolabilidade de sua residência e as agressões praticadas, revoltou-se, mas obteve, como resposta do policial, palavras de injúria e ameaça de morte. Denunciou que os policiais agressores contaram com a cooperação de outros colegas de profissão que estavam em motos não identificadas. Os referidos policiais, na tentativa de incriminarem as vítimas, forjaram uma situação onde alegaram ter encontrado drogas no interior de sua residência:

Aos quinze de outubro de 2004, uma senhora compareceu à sede da Corregedoria e apresentou a queixa de que se encontrava em sua residência, com seus dois filhos, quando os policiais chegaram ao local e agrediram os rapazes com chutes e golpes de cassetetes. A declarante afirmou que os garotos haviam sido acusados de tráfico de drogas e que estavam escondendo maconha em casa. Ao ver a situação, solicitou aos policiais que parassem com as agressões. No que não foi atendida, pois um dos sindicados respondeu "sai daqui sua velha sem vergonha, sua vagabunda, rapariga, pilantra, que acoita tudo o que não presta. Sai daqui se não the dou um tiro". Em seguida, chegaram mais policiais em motos não identificados e forjaram uma situação em que haviam encontrado maconha na casa da declarante, o que resultou na prisão dos dois rapazes. (PROCESSO EM SINDICÂNCIA, denúncia apresentada por um civil, em outubro de 2004)

Em outra sindicância, o constrangimento decorreu, como conta a declarante, quando os policiais ameaçaram forjar um flagrante logo depois de "aprisionarem" as vítimas no interior de sua residência. Inconformada, conta que pediu aos policiais para não fazerem isso, pois ela não devia nada. A vítima considera que a ação desferida por um dos policiais ocorreu por vingança, pelo fato 
de tê-lo denunciado em outra ocorrência ao Comando Geral. Considera-se lesada, não só em sua integridade moral, por ter sido ameaçada com palavras de injúrias e difamação, e com ameaças de violência à sua integridade física, o que só não ocorreu de fato, devido à intervenção de seu filho que entrou em luta corporal com o policial:

Aos 15 do mês de fevereiro de 2007, uma senhora compareceu à sede da Corregedoria para prestar queixa contra a invasão de residência e agressão física, praticada por policiais militares, no bairro Parque São José. Conta a inquirida que estava sentada em frente à sua residência, quando chegaram três policiais militares, que ordenaram que seus filhos e outros rapazes se encostassem à parede, para que fosse feita uma busca de arma, que o policial encontrou a quantia de três reais no bolso de seu filho, mas que disse que este dinheiro ela tinha dado para ele. O policial rasgou o dinheiro e jogou dizendo "taí seu dinheiro" e ordenou que todos entrassem e, após invadir a residência, mandou que ela se sentasse no chão. Ela questionou que estava de saia e não seria possível e o policial disse que iria quebrar todos os que estavam ali, que o seu filho disse que não aceitaria que a declarante fosse agredida dentro de casa. Após isso, ouviu que um deles falava ao telefone dizendo que todos já estavam dentro de casa e só faltava a droga para fazer o flagrante; seu filho pediu que não forjasse um flagrante, pois ela não devia nada. 0 soldado tentou algemar seu filho, mas não conseguiu, neste momento, correu em busca de ajuda e os policiais a seguiram com a arma em punho. Com a saída da declarante, o rapaz fechou a porta por dentro, impedindo que o polícia entrasse novamente, este pediu ajuda ao outro e entraram em vias de fato, desferindo golpes de cassetete. A declarante ao retornar para sua casa, os policiais começaram a agredi-la verbalmente, chamando-a de vagabunda e rapariga. Que a declarante já havia denunciado o policial ao comando geral da polícia por agressão e que o policial teria ido à sua casa por vingança pela denúncia feita contra ele. Ao questionar por qual motivo seria presa, quase foi agredida com cassetete, só não foi porque outro policial interveio. (PROCESSO EM SINDICÂNCIA, denúncia apresentada por um civil em Fevereiro de 2007)

Além das práticas de extorsão, abuso de autoridade e agressão física, o consumo de álcool é apontado pelos denunciantes como um problema para o 
"bom desempenho do policial". No caso abaixo descrito, o sindicado queixou-se de que os policiais não se portaram como "profissionais representantes da lei", ao estarem sob o efeito de bebida alcoólica. Relata que um deles, aparentemente, alcoolizado disse "deixa que eu resolvo":

Aos 11 do mês de Julho de 2003, um senhor compareceu à ouvidoria da Corregedoria de polícia para denunciar agressão física e danos praticados por um policial militar, no bairro Jardim Iracema. Conta o denunciante que se encontrava em sua residência, quando, inesperadamente, passaram a chutar a porta da frente de sua residência, que disseram ser a polícia, chamando de vagabundo, mandando que a abrisse a porta e que, ao abri-la, foi puxado e encostado na parede, que um dos policiais o agrediu com um soco no tórax, determinando que ele dissesse onde estava o meliante que havia pulado para o quintal de sua casa. Que havia dito não ter possibilidade de que alguém tivesse pulado para o seu quintal e o militar, sempre de arma em punho, encostou o revólver na cabeça do declarante, mandando que dissesse onde estavam os bandidos. A sua esposa, ao declarar que não havia ninguém na casa, somente ela e seu esposo, o policial mandou que ficasse calada, senão seria levada presa, que outro policial disse "deixe que eu resolvo". Percebeu pelo cheiro que este policial havia consumido bebida alcoólica. (PROCESSO EM SINDICÂNCIA, denúncia apresentada por um civil, em julho de 2003)

Em outro caso, queixou-se a declarante que, ao reclamar dos problemas ocasionados por uma área verde em seu bairro, foi questionada por um policial, que não concordou com o corte de uma árvore. No conflito, o policial desferiu uma tapa em seu rosto, ao cair, ainda foi arrastada e, em seguida, algemada. Denunciou que o referido policial, no momento da agressão, encontrava-se bêbado:

Aos 22 de mês de Fevereiro de 2005, compareceu uma senhora à Corregedoria para denunciar uma ofensa moral e agressão física, causados por um policial militar, no bairro do Conjunto Nova Metrópole, Caucaia. Conta a declarante que estava na frente de sua casa, conversando com as vizinhas, que o assunto era uma área verde em seu bairro, que estava sendo invadida pelo mato e estava prejudicando a saúde, devido à incidência de ratos e baratas. Na ocasião, um policial se aproximou e disse que ela não poderia derrubar a árvore e ela respondeu com uma ofensa moral ao policial, e, como resposta, levou uma tapa no rosto, que caiu e foi 
arrastada pelo policial e depois algemada. A viatura foi acionada e, quando chegou, mandou que fossem retiradas as algemas, pois todos seriam encaminhados à delegacia, para prestar depoimento. A declarante afirma que o policial estava bêbado e sugeriu que deixasse o caso para lá. (PROCESSO EM SINDICÂNCIA, denúncia apresentada por um civil em fevereiro de 2005)

Após alguns desses incidentes praticados por policiais militares em serviço ou fora das atividades de patrulhamento e, particularmente, por conta do envolvimento de um policial militar no crime de homicídio de dois jovens médicos no interior do Estado, o, então, Secretário de Segurança Pública do Estado do Ceará, Roberto Monteiro, publicou uma portaria, proibindo o consumo de álcool. Além dessa medida, ficou estabelecido que os policiais passassem por um teste de agressividade ${ }^{5}$, para avaliar a habilidade desses agentes no policiamento ostensivo.

\section{Violência policial - insegurança ou ausência de diálogo?}

No entendimento da violência como contrária à capacidade de consentimento e livre obediência à autoridade constituída, Arendt (2003) questiona que o problema fundamental dos governos está na dificuldade em equacionar a aplicação da lei com o respeito ao cidadão. Por essa razão, considera que, em contextos políticos onde o desrespeito ao cidadão está em jogo, as experiências históricas anunciam uma "crise de autoridade" no mundo moderno e contemporâneo Lefort (1991), ao pensar o político como experiência de liberdade, acrescenta ao questionamento de Hannah Arendt que, em um regime democrático, são experiências de liberdade que permitem aos homens políticos justificarem a legitimidade do poder.

A relação entre experiência de liberdade e medo da violência, entretanto, sofreu alterações ao longo dos tempos e acontecimentos históricos. Ao tratar do medo da violência, Duby (1999, p. 113) descreve como as mudanças nos padrões de comportamento nas sociedades, ao final da Idade Média, na França, possibilitaram um sentimento diferente sobre o medo. Este passou a ser percebido como parte do processo de pacificação social, ou seja, o medo da violência é, antes de tudo, "um freio à erupção das libidos agressivas". Conta que, nas cidades medievais, existiam "zonas pacíficas", a exemplo dos mercados públicos, onde todos eram constantemente vigiados. Buscava-se evitar, por meio da disseminação do medo, que o exercício da violência ocorresse de acordo com as regras estabelecidas pelos grupos pacificadores.
5. pós alguns casos de agressão envolvendo policiais militares, o secretário de segurança decretou que os policiais deveriam se submeter a um teste de agressividade. Nesse teste, os policiais passariam por avaliações psicológicas, cujo principal objetivo seria avaliar as condições dos mesmos para atuarem no trabalho ostensivo.

6. Hannah Arendt atesta sobre o próprio desaparecimento da autoridade no mundo moderno, devido ao abismo entre a tradição e modernidade. Considera que, quando os meios externos de coerção e força são usados, "a autoridade em si mesmo fracassou" (2003, p. 129). 
Nas comparações entre as sociedades aristocráticas ou guerreiras e as sociedades burguesas, Chauí (1989) considera que, nessas últimas, o sentimento de medo passou por mudanças em sua estrutura, através do surgimento da concepção de sujeito social, político e histórico, no sentido de desvincular o medo como temor que os sujeitos sociais têm de seus semelhantes. Nesse caso, o medo surge como uma ameaça à convivência pacifica, pois, em sua manifestação, é comum a associação entre medo e perda de liberdade. Por esse motivo, Sennetti (2001), ao tratar do conceito de autoridade, sugere que qualquer forma de governo que tenha por correlato o emprego do medo e do terror é, portanto, questionável.

As agressões praticadas no exercício do "poder polícia”, segundo Muniz (2006), são resultantes de uma situação de medo e insegurança em que os próprios policiais ou se "percebem inferiores ou se sentem menos sujeitos de direito do que os cidadãos comuns" e, ao invés de recorrerem aos seus direitos como cidadãos, veem na violência uma maneira de justificar a sua posição de inferioridade. Nesse caso, o sentimento de "inferioridade", como argumenta Elias (1993), pode gerar um estado de inquietação, em que, em decorrência da ausência de "lutas competitivas" pelas chances de prestígio e reconhecimento que a posição oferece, não seria possível aos representantes do monopólio da violência física capitalizarem o poder social de acordo com os benefícios destes como membros de uma "classe distinta".

As explicações para as práticas agressivas no exercício de policiamento ostensivo podem estar, assim, relacionadas não só a uma reciprocidade negativa ou ao que Simmel (1983) definiu como violência pela violência, bem como à ausência de regras formais que permitem aos agentes sociais capitalizarem os benefícios do poder e prestígio relacionados à posição que ocupam no campo social como detentores legítimos do monopólio da violência. Agindo dessa forma, é possível que não ocorra um mínimo de entendimento racional sobre o reconhecimento da autoridade policial facultada aos agentes, quando aceitam as premissas válidas do direito pautado no entendimento mútuo (HABERMAS, 1997).

A espontaneidade presente nas agressões praticadas pelos policiais sugere uma agressividade que, na maioria das vezes, extrapola qualquer vontade de entendimento racional entre agressor e vítima. Em situações em que as vítimas costumam buscar encontrar um entendimento, por exemplo, não é incomum os sindicados obterem, como resposta às suas "reivindicações", agressões morais ou até mesmo ameaças de morte. Nesses casos, a possibilidade de que o agressor policial revide é maior se comparada às expectativas da vítima em encontrar uma solução "pacífica" para o conflito respaldado pelo diálogo: 
Aos 27 do mês de março de 2003, um senhor compareceu à ouvidoria da Corregedoria de polícia para prestar queixa de abuso de autoridade praticada por policiais civis, no bairro Vicente Pinzón. Conta o declarante que se encontrava em sua residência, quando sua casa foi invadida por policiais civis, à procura de filho da declarante, que havia sido apontado por um menor como autor de um assalto a um caminhão, mas retrucou que seu filho não havia cometido o crime e que iria apresentá-lo ao delegado. Então, se apresentou na delegacia e solicitou que a pessoa que havia acusado seu filho pudesse identificá-lo. Na ocasião, o menor, ao fazer o reconhecimento, foi constatado que ele não havia de fato envolvimento no assalto, que o comissário falou para o declarante que havia sido um engano e que poderiam ir embora, ainda tentou conversar com o inspetor que procedeu a busca, mas este não quis conversa. (PROCESSO EM SINDICÂNCIA, denúncia apresentada por um civil, em março de 2003)

Em outro caso, o sindicado mesmo solicitando com educação que fossem devolvidos seus documentos, o agressor recusou, jogando-os no chão. Conta que no momento em que foi colocado na viatura, sob protesto da população, os policiais revidaram com tiros para dispersar as pessoas que faziam o protesto. No caminho até a delegacia, relata que, a todo tempo, foi destratado pelos policiais que o chamavam de "vagabundo", assim como sua companheira e sua mãe:

Aos 29 de mês de maio de 2006, um senhor compareceu à sede da Corregedoria para prestar queixa de agressão física, praticada por policiais militares, no bairro do Serviluz. Conta que estava na residência de sua mãe, quando chegou uma viatura; que acusaram o declarante de ter participado de um tiroteio e que precisariam levá-lo para fazer um reconhecimento. No momento, identificou-se e disse não ter participado, acrescentando ser trabalhador. Não tendo os documentos, sua mãe entregou um extrato, que foi jogado ao chão pelos policiais, dizendo que não interessava. 0 declarante, mesmo pedindo que tivessem educação, entregando de volta o documento, não foi prontamente atendido. Ao ser colocado na viatura, sob protesto da população, a seu favor, um dos policiais revidou, empurrando e agredindo fisicamente sua companheira com um tapa e que seu filho também fora empurrado pelo mesmo policial, que, no momento, investiu contra a ação, entrando os dois em vias de fato, sendo o declarante, 
algemado e conduzido para o reconhecimento. Disse que, quando transitava por uma rua do bairro, dentro da viatura, fora agredido novamente com um murro à face que resultou em um ferimento, estando algemado e imobilizado. A todo tempo foi destratado pelos policiais que o chamaram de vagabundo, assim como sua companheira e mãe. No momento de sua condução, conta que os policiais atiraram para cima, para dispersar a população, que estava fazendo o protesto contra a sua prisão. Conta que revidou a agressão, pelo fato destes policiais terem destratado sua companheira e sua mãe e, na delegacia, o delegado plantonista reclamou dos policiais, pois, o declarante encontrava-se de joelho e chutavamno, que nunca foi preso, sendo uma pessoa honesta e trabaIhadora, não sabendo o motivo de ter sido envolvido no caso. (PROCESSO EM SINDICÂNCIA, denúncia apresentada por um civil em Maio de 2006)

Em outro caso similar, a sindicada sugere a impossibilidade de entendimento com o policial e conta que, na tentativa de explicar a necessidade de "representar" seu filho, pelo fato de este estar participando de um programa de reabilitação, não foi devidamente compreendida em sua justificativa, ao obter, como resposta, agressões morais, praticadas por policiais militares que afirmaram, categoricamente: "a Senhora, que tem filho vagabundo, que aguente as consequências":

Aos 25 do mês de Janeiro de 2005, uma senhora compareceu à sede da Corregedoria para denunciar invasão de residência, no bairro da Praia do Futuro. Segundo a declarante, conta que se encontrava em sua residência, quando escutou um barulho, como se fosse alguém forçando a porta. Quando se dirigiu para olhar o que estava ocorrendo, fora impedida por um policial militar e, quando disse que iria representar contra os mesmos, ouviu dos policiais a seguinte resposta "a Senhora que tem filho vagabundo que aguente as consequências". Confirmou que seu filho já se envolveu em ocorrências policiais, mas que hoje estaria participando de um programa de reabilitação do governo e que não mais comete delitos. Os policiais não apresentaram mandato de busca e apreensão e, segundo eles, havia ocorrido um assalto e deduziram que o envolvido seria seu filho, mas o mesmo não se encontrava em casa, pois, estava no programa de reabilitação. (PROCESSO EM SINDICÂNCIA, denúncia apresentada por um civil, em janeiro de 2005) 
Nos autos dos processos, o abuso de autoridade praticado por policiais militares e civis é apontado pelos sindicados como uma das causas para um comportamento agressivo nas operações de abordagem e investigação. Como se queixa a sindicada, que é vizinha do policial que a agrediu, este é temido pela população, pelo fato de ser uma pessoa agressiva e, costumeiramente, usar da autoridade que lhe é conferida para impor medo:

Aos 23 do mês de julho de 2002, compareceu uma senhora denunciando abuso de autoridade contra sua pessoa, tendo sido causado por um policial militar, no bairro Alto da Mangueira, em Maracanaú. Declarou que é vizinha do policial e que o mesmo seria bastante agressivo e violento, tanto que a maioria da vizinhança tem medo e, portanto, evitaria se envolver em confusões e intrigas, temendo a atitude do referido policial. Conta que, no dia 21 julho de 2002, estava em casa, quando alguns indivíduos que se encontravam em uma esquina soltaram bombas. No momento, o policial foi tomar satisfação do ocorrido, em seguida, o policial foi até a sua casa e retornou com uma arma de fogo para amedrontar os rapazes, que haviam soltado as bombas. Conta também que o filho do PM pegou uma faca e desferiu alguns golpes contra o animal de estimação que ela possuía e que poderia fazer o mesmo com ela. Ao saber do ocorrido, o policial foi até sua casa e se dirigiu de forma ríspida e ameaçadora para o seu marido, chamando-o de "negro sem-vergonha", afirmando, ainda, que, na ocasião, poderia sair um defunto. Assim, o policial apontou uma arma em sua direção e de seus familiares, efetuando um disparo, mas, por intervenção de seus filhos, o tiro foi para o alto. Acrescentou que, apesar de muitos vizinhos terem presenciado o ocorrido, eles têm medo de prestar informações sobre o fato. (PROCESSO EM SINDICÂNCIA, denúncia apresentada por um civil, em julho de 2002)

O policial acima citado foi descrito pela denunciante como "bastante agressivo e violento". Com base em seu depoimento, o Corregedor alegou que o mesmo procedeu até de forma correta, ao buscar coibir a ação de marginais em seu bairro, mas julgou improcedente sua atitude contra as pessoas que não haviam cometido qualquer tipo de crimes e que, antes do acontecido, as relações entre eles eram amistosas, tendo sido desgastadas, após este conflito.

O policial que recorre à autoridade que lhe é conferida para impor medo pela violência, abre, portanto, um precedente para questionar o papel das polícias em sociedades democráticas de direito. Em situações onde a intervenção 
policial não é considerada legítima e permite a contestação, é possível pôr em dúvida a justificativa do "desacato a autoridade" como expressão de uma ameaça, cujo objetivo é impor o poder pelo medo da violência. No caso descrito pelo sindicado, o policial civil, após invadir sua residência, disse que prenderia a todos que estavam na residência, caso as vítimas não entregassem os objetos considerados ilícitos:

Aos 03 do mês de junho de 2005, um senhor compareceu à Corregedoria para prestar queixa de invasão de residência, praticada por policiais civis da Delegacia de Narcóticos - DENARC, no bairro Parque Santa Filomena, em Messejana. Conta que foi avisado por um vizinho que policiais estavam invadindo sua residência e, ao chegar ao local, foi informado que havia uma denúncia de que o declarante guardava drogas, armas pesadas de assalto e dinheiro. $O$ declarante disse que era um cidadão e uma pessoa pobre e que não aceitaria guardar produtos ilícitos em sua residência. Mesmo assim, o policial civil exigiu que entregasse os objetos, sob ameaça de murros na cara e que o prenderia por desacato a autoridade. Os policiais entraram na casa, vasculharam, mas não encontraram nada, e, durante a busca, encontraram a identidade de seu filho, já falecido, e que os polícias acusaram o seu filho de marginal, destrataram também sua esposa. (PROCESSO EM SINDICÂNCIA, denúncia apresentada por um civil, em junho de 2005)

Em outro caso, as agressões são questionadas como inconsequentes, diante não só das justificativas do sindicado, em afirmar categoricamente que era um trabalhador, bem como da forma pelo qual os policiais agiram, ao usar de violência desnecessária contra o sindicado, chamando-o de vagabundo. Ao tentar prestar uma denúncia contra os policiais militares, no quartel da polícia, ao invés de ter assistência e informação necessária para reivindicar seus direitos foi, ao contrário, preso, por "desacato à autoridade":

Consta nos autos de um processo denúncia em que a vítima se queixa de lesão corporal praticada por policiais militares. Segundo o denunciante, no dia 01 de junho de 2003, foi a um bar, no Conjunto Esperança, e pediu uma cerveja, todavia, não foi atendido, pois a proprietária informou que o bar estava fechado, por determinação da polícia militar. Ao insistir no pedido, apareceu um policial militar e perguntou se o declarante estava surdo, chamando-o ainda de vagabundo. Nesse instante retrucou e disse que não era vagabundo, 
que tinha direitos, mas os três policiais passaram a agredir o declarante com tapas e chutes. Cessadas as agressões, o denunciante foi até o batalhão da polícia para prestar queixa do ocorrido, mas os policiais agressores chegaram ao local e deram voz de prisão e o conduziram à delegacia. (PROCESSO SOB SINDICÂNCIA, denúncia apresentada por um civil, em junho de 2003)

No que se refere a esse caso, o parecer final do corregedor auxiliar se manifestou favorável à punição disciplinar. Determinou, dessa forma, que, de acordo com os autos do processo, é incontestável o procedimento incorreto dos citados policiais ao lesionar o denunciante. Fato este confirmado de forma técnica (com base no exame de corpo delito), bem como das testemunhas arroladas no processo, que validaram a materialidade do fato.

Em um caso de extorsão, a vítima prestou queixa, ao denunciar que os policiais civis, mesmo não encontrando nada que pudesse incriminá-lo, não o deixaram livre da cobrança de propina, quando exigiram a quantia de $\mathrm{R} \$ 1.500$ para liberálo. Acrescenta aos autos do processo que, em outra ocasião, já havia sido vítima, mas, por medo de represálias, não encaminhou o caso à Corregedoria:

Aos 24 do mês de Novembro de 2004, um senhor compareceu à Delegacia de Narcóticos - DENARC, para denunciar a ação de extorsão ocorrida no bairro do Pirambu. Conta o declarante que se encontrava em uma Avenida de Fortaleza, em sua locadora, quando chegaram dois homens que se identificaram como policiais, os quais disseram que havia denúncias contra a sua pessoa, então, realizaram uma busca, mas não encontram nada de irregular e procederam a uma revista em sua contadora e também não encontraram nada de irregular e, a partir desse momento, começaram uma busca de drogas, que não foram encontradas. Contou que outros já haviam ido a seu estabelecimento, mas nada havia sido encontrado, então, os policiais da delegacia o extorquiram com a quantia de $\mathrm{R} \$ 1.500,00$ (hum mil e quinhentos reais). Antes, quando foi vítima pela primeira vez, já havia feito um boletim de ocorrência - $\mathrm{BO}$, mas que não tinha enviado o caso à Corregedoria devido ao medo de represálias. Disse que compareceu à delegacia em busca de paz e tranquilidade, para levar uma vida normalmente e que quer punição exemplar para os supostos policiais militares, que nunca havia sido preso e nem processado e que não é usuário de drogas. (PROCESSO EM SINDICÂNCIA, denúncia apresentada por um civil, em novembro de 2004) 
Após formalizar a denúncia, posteriormente, em setembro de 2006, o declarante acima citado compareceu à Corregedoria, acompanhado de seu advogado, solicitando que o caso fosse encerrado. Alegou que não queria falar mais nada e, assim, não poderia colaborar com mais informações sobre o caso, alegando que queria viver em paz e sossegado. Acrescentou que, na condição de vítima, teme por sua vida e lamentou o fato, ao denunciar a sensação de medo e constrangimentos aos moradores de seu bairro, causada pelo comportamento agressivo do referido policial.

\section{Conclusão}

A análise das denúncias apresentadas à Corregedoria revela que, para algumas pessoas abordadas nas ruas, ainda existe um sentimento de medo em se tornarem vítimas de agressão por parte de policiais que, sob o ponto de vista legal e legítimo, deveriam prestar segurança ao cidadão. Esse dado contribui para que, em determinados casos, os sindicados se sintam pressionados pelos policiais agressores a não levarem em frente a denúncia. Para os corregedores de polícias, o problema decorrente dessa situação está relacionado ao aumento da impunidade e à criminalização indevida das vítimas, através de ações forjadas para condená-las.

O medo da violência policial alerta para a circunstância de que as intervenções policiais autoritárias contrariam a valorização do respeito que, segundo Sennetti (2004), está relacionado aos atributos de caráter quando se faz necessário, nas relações, "tratar com respeito à necessidade percebida em outro em uma apresentação conjunta". A perspectiva de reconhecimento dos policiais como "representantes da lei" sugere, no entanto, um questionamento acerca da compatibilidade entre o uso da força física e o respeito aos valores de proteção à cidadania.

Pela análise dos processos denúncias, é possível sugerir que, nos casos onde é constante o desrespeito ao cidadão, as contradições apontam para a justificativa tanto do argumento da lei e da ordem ou do preconceito velado em práticas agressivas e preconceituosas, que criminalizam não só a pobreza, pelo fato do apenado, geralmente, ser um infrator e possuir os atributos depreciativos que o qualificam como criminoso em potencial, mas, antes de tudo, revelam práticas desumanas, que se exercem através da não prestação dos serviços de segurança à população, particularmente, o cidadão pobre, que recorre à justiça para resolver seus problemas sociais.

Wacquant (2001, p. 35) observa que "a polícia, quando é considerada uma força estranha pela comunidade, torna-se incapaz para cumprir outro papel, que 
não seja o puramente repressivo". Os casos analisados apontam que os atributos depreciativos contribuem para a intolerância como uma barreira nas relações entre as polícias e a sociedade. Por essa razão Touraine (1998), questiona sobre a possibilidade de vivermos juntos uns com os outros, respeitando as diferenças e a unidade que determina a vida coletiva. Complementa Touraine que o primeiro obstáculo a ser superado para que possamos viver juntos em coletividade é a resistência às barreiras sociais impostas pela violência.

O argumento de que a violência nos deixa no vazio, sem defesa, diante de casos de segregação, racismo, intolerância à igualdade, surge como um contraponto aos mecanismos de controle social em uma sociedade democrática de direitos, que, segundo Habermas (2002), baseia-se no comprometimento com os acordos racionais, a justiça e o exercício livre da cidadania na vida pública.

Abstract: In Brazil, the transition from the state of exception to the democratic rule of law contributed to significant changes in the design of policing. Among other changes, are included: external control of the police internal affairs, investigation and punishment for "bad cops", the involvement of the police and the population in community councils, seeking improvements to security issues, concerns by the police with a different treatment approaches for citizens and those who seek to provide the police complaints, investment in intellectual training in police academies, requirements for the Brazilian government to obey international agreements that establish the purpose of torture as a research method. This process has found, however, some obstacles and resistance. In this paper, results of a survey conducted between the years 1999 to 2007 the Unified Police Magistrate in Fortaleza (CE) presents some complaints involving military and civilian police in criminal acts punishable as disciplinary offenses. As a conclusion of the research, I argue that, because of the lack of dialogue and peaceful rules between police and civilians, police violence has compromised the expectations of the civilizing process that is exerted by the strengthening of the monopoly on the legitimate use of physical force.

Keywords: Police Practices, External Control, Monopoly of Violence, Police Violence, Community Policing

Referências

ARENDT, Hannah. Sobre a violência. Rio de Janeiro: Relume Dumará, 1994. . Entre o passado e o futuro. São Paulo: Editora Perspectiva.

BOURDIEU, Pierre. A dominação masculina. Rio de Janeiro: Bertrand Brasil, 2002. 
CHAUÍ, Marilena. "Direitos humanos e medo". In: Direitos humanos e. São Paulo: Editora Brasiliense, 1989.

DAHRENDORF. Ralf. A lei e a ordem. Rio de Janeiro: Instituto Liberal, 1997.

ELIAS, Nobert. O Processo civilizador. Rio de Janeiro: Jorge Zahar, 1993.

. Os Alemães: a luta pelo poder e a evolução do habitus nos séculos XIX. Rio de Janeiro: Jorge Zahar, 1997.

DUBY, Georges. Ano 1000, ano 2000 na pista de nossos medos. São Paulo: Editora UNESP/ Imprensa Oficial do Estado, 1999.

FOUCAULT, Michel. Vigiar e Punir: história da violência nas prisões. 8a ed. Petrópolis: Vozes, 1987.

HABERMAS, Jurgen. Direito e democracia: entre a faticidade e validade, v. I. Rio de Janeiro: Tempo Brasileiro, 1997.

A inclusão do outro. São Paulo: Edições Loyola, 2002.

KANT DE LIMA, Roberto \& MIRANDA, Ana Paula Mendes de. "Estado, direito e sociedade: a segurança e a ordem pública em uma perspectiva comparada". In: Susana Durão \& Marcio Darck. (Org.). Polícia, Segurança e Ordem Pública: Perspectivas Portuguesas e Brasileiras. 1a ed. Lisboa, Portugal: Imprensa de Ciências Sociais, v. 1, p. 73-100, 2012.

LEFORT, Claude. Pensando o político: ensaios sobre democracia, revolução e liberdade. Rio de Janeiro: Paz e Terra, 1991.

LEMGRUBRER, Julita e outros. Quem vigia os vigias? Um estudo sobre controle externos da polícia no Brasil. Rio de Janeiro: Record, 2003.

MISSE, M. "As ligações perigosas: mercado informal ilegal, narcotráfico e violência no Rio". Contemporaneidade e Educação, Rio de Janeiro, v. 1, p. 93-116, 1997.

MUNIZ, Jacqueline. "Direitos humanos na polícia”. In: Renato Sérgio de Lima, \& Liana de Paula (Org.).Segurança pública e violência: o Estado está cumprindo seu papel?. São Paulo: Contexto, 2006.

PAIXÃO e outros. "Métodos e acidentes de trabalho: violência, legalidade e policial". Análise \& Conjuntura, Belo Horizonte, v. 7, n. 2 e 3, maio/dez, 1992.

SIMMEL, Gerg. Georg Simmel: sociologia. In: Evaristo de Morais Filho (org.). São Paulo: Ática, 1983.

SOARES, Luiz Eduardo. Elite da Tropa. Rio de Janeiro: Objetiva, 2006. 
TAVARES DOS SANTOS, José Vicente. "A arma e a flor: formação da organização policial, consenso e violência". Tempo Social. Revista de Sociologia da USP, Departamento de Sociologia, Faculdade de Filosofia, Letras e Ciências Humanas, Universidade de São Paulo, v. 9, no 1, São Paulo, SP: USP, FFLCH, 1989.

TOURAINE, Alain. Poderemos viver juntos? iguais e diferentes, 2. Edição. Rio de Janeiro: Editora Vozes, 1998.

ZALUAR, Alba. "Para não dizer que não falei de samba: os enigmas da violência no Brasil". In: Fernando A. Novais (Org.) História da vida privada no Brasil. São Paulo: Companhia das Letras, 1998.

WEBER, Max. Economia e Sociedade: fundamentos da sociologia compreensiva. Brasília: Editora Universidade de Brasília, v. 1, 1991.

Economia e Sociedade: fundamentos da sociologia compreensiva. Brasília: Editora Universidade de Brasília, v. 2, 1999.

VELASCO, Ivan de Andrade. As seduções da ordem: violência, criminalidade e administração da justiça, Minas Gerais - século 19. São Paulo: EDUSC, 2004 